\title{
Me, who?
}

\section{(Un)telling whiteness within and beyond MeToo}

\author{
By Elisabeth Bruun Gullach \& Maya Acharya \\ founders of (un)told pages, a Copenhagen-based \\ literature festival featuring only Black, Indigenous \\ and People of Colour authors
}

\begin{abstract}
"What would it look like to leave the house and not be afraid of being bashed? what would it mean to leave the house and not be bashed? what would it mean to leave the house and not be harassed? what would it mean to leave the house and not be objectified? what would it mean to leave the house and not be gendered? what would it mean to no longer be forced to do the work of gender? what would it mean to my own body? what would it mean to have a self beyond my body?"
\end{abstract}

(Vaid-Menon, 2017)

Since we're in the business of words, let's start there. \#Metoo. A worldwide hashtag that has radically changed the public conversation around sexual violence. Two short syllables that hold so much information about positioning, power and narrative.

'Me too'. Me contains specificity - a definite pronoun - a whole, full-fleshed individual, unique in their complexity and experience. Me is personal. Me is particular. The adverb 'too' functions as an adjunctive - added to the former to imply an addition, a reflection, an expression of unanimity. But what or who is being amplified? Who is speaking and who is responding?

The 'Me Too' hashtag started as a grassroots campaign, a rallying cry, founded by a Black woman in the US, Tarana Burke, to support Black and women of colour who were survivors of sexual violence. A way for these women to share their stories and find spaces and resources of support. Burke was doing this work a full decade before rich, white, cis Hollywood celebrities became the mainstream faces of the movement packaged as a hashtag. It should come as no surprise that MeToo became a household name only after it was whitewashed and co-opted by a powerful elite. This is part of a long history of the erasure of Black women and femmes who, historically, have been at the forefront of movements for social justice. Moreover, we know that sexual violence is perpetrated disproportionately towards Black trans women ${ }^{1}$; sex workers ${ }^{2}$; and economically marginalised women and non-binary BIPOC (Black, Indigenous and People of Colour) ${ }^{3}$.

This selective narrative is symptomatic of white feminism, how feminism is made white (Ahmed, 2007) before it can become palatable, before it can 'go viral', before its concerns and 
efforts are validated by a broader public. This is a feminism that purports to be about liberation but which is premised on eradication, on serving the interests of a particular kind of woman (usually white, cis, straight, thin, able bodied, middle class) while neglecting those who don't fit into its framework. None of this is new. Audre Lorde was writing on the duplicity of white women and the importance of acknowledging difference in feminist movements half a century ago - on the importance of holding apart in order to bring together (Lorde, 2017).

Feminism does not take place in a social and political vacuum. What we should be paying attention to is how these stories get spun, when they are legitimised, who become the protagonists and who get delegated to the background.

In literature, the space we found comfort in growing up as mixed-race women in Scandinavia, the landscape is much the same. Books, which meant so much to us, were emblematic of the way in which whiteness was a lens through which stories had to be filtered in order to make sense, in order to become valid, in order to be deemed 'relatable'. Whiteness was the norm within which everything was assumed, and when there were stories featuring BIPOC characters, they were shrouded in pain and trauma; stories of forced marriage, of kidnapping and assault, of backwards Brown and Black families, of poverty, of struggle. Or otherwise they would fit neatly into racist caricature: loyal sidekick, villain, oracle, or one of the many exhausted tropes that are allocated to BIPOC. The main characters, the nuanced characters, the characters allowed more than a footnote, were the white ones. These characters (never explicitly described as white, they just were) were afforded a rich inner life, could embody contradictions, while the few BIPOC characters (their non-whiteness somehow warranting explicit mention) either faded into the backdrop or functioned as two-dimensional props.

Reality reflects fiction. Just as white faces saturate pages, MeToo is emblematic of whiteness being positioned front and centre, becoming the premise for stories that are deemed worthy of attention. This is true of MeToo and it is true of art. When it comes to the representation of sexual violence in literature, it is not only that stories are overwhelmingly white, but that they are assumed to be for a white audience. When BIPOC are given the chance to tell their stories, they are expected to divulge trauma in order to legitimise their experiences. A confessional to satiate the white palette. This requires so much from BIPOC writers - a constant negotiation of gaze and agency - of being denied the creative freedom that white authors are granted, because the conjecture will be that you are speaking 'on behalf of'. The risk is that your personal experience will be hijacked and wielded against you, or that your creativity will be distilled into personal experience and autobiography in the first place. As Vivek Shraya pertinently writes:

"I have always been disturbed by this transition, by the reality that often the only way to capture someone's attention and to encourage them to recognize their own internal biases (and to work to alter them) is to confront them with sensational stories of suffering. Why is humanity only seen or cared about when I share the ways in which I have been victimized and violated?" (Shraya, 2018).

We want there to be a turning, a movement; meaning both mobilisation - a campaign such as MeToo - but also a shift, a different orientation, a striving towards a new focus, an alternative version of the tale. One where BIPOC authors are not forced to embody a specific trauma or character. We turn to the story in which BIPOC, especially those who are queer and trans, are given the space to encompass full narratives. To be acknowledged as unabridged, nuanced beings with a multitude of experiences and life forms. To be independent of the white, cis barometre that determines the extent to which their feelings can be 'universalised'. A story where a Black woman creates a hashtag that is not hijacked by whiteness before gaining widespread support. Where those coopting the work of Black trans and gender non-conforming people acknowledge the shoulders on which they stand, the groundwork laid for them. Turn, as in change. 


\section{Notes}

1 https://www.transequality.org/sites/default/files/docs/usts/USTS\%20Full\%20Report\%20-\%20 FINAL\%201.6.17.pdf

2 https://www.ncbi.nlm.nih.gov/pmc/articles/PMC3987574/

3 https://www.transequality.org/sites/default/files/docs/usts/USTS\%20Full\%20Report\%20-\%20FINAL\%20 1.6.17.pdf

\section{References}

Ahmed, S. 2007. A phenomenology of whiteness. Feminist Theory. 8(2),149-168.

Deering, K. N., et al. 2014. A Systematic Review of the Correlates of Violence Against Sex Workers. American

Journal of Public Health. 104(5): e42-e54.

Lorde, A. 2017. Your Silence Will Not Protect You. London: Silver Press.

Shraya, V. 2018. I am Afraid of Men, Men are Afraid of me. Toronto: Penguin Canada.

Vaid-Menon, A. 2017. Femme in Public. Self-published.

The report of the U.S. transgender survey, 2015: https://www.transequality.org/sites/default/files/docs/ usts/USTS\%20Full\%20Report\%20-\%20FINAL\%201.6.17.pdf

\section{Starting point for further reading}

Alabanza, T. 2018. Burgerz. London: Oberon Books

Ali, N. 2019. What We're Told Not To Talk About (But We're Going To Anyway) Women's Voices From East

London to Ethiopia. London: Penguin.

Belcourt, B. 2017. This World Is A Wound. Calgary: Frontenac House.

Brown, A. M. 2019. Pleasure Activism. Chico: AK Press.

Daley-Ward, Y. 2018. The Terrible: A Storyteller's Memoir. London: Penguin.

Gatwood, O. 2019. Life Of The Party. London: Transworld Publishers.

Gay. R. 2017. Hunger. New York: Harper Collins.

Machado, C. M. 2020. In The Dream House. Minneapolis: Gray Wolf Press.

Miller, C. 2019. Know My Name. New York: Viking Press.

Nin, A. 2021. Bodies In A Circle. Forthcoming from Astra Publishing.

Olufemi, L. 2020. Feminism, Interrupted. Disrupting Power. London: Pluto Press.

Reid, K. 2019. Such A Fun Age. New York: G.P. Putnam's Sons.

Shraya, V. 2018. I'm Afraid Of Men. Men Are Afraid Of Me. Penguin Random House Canada.

Vaid-Menon, A. 2017. Femme in Public. Self-published.

Zhang, J. 2020. My Baby First Birthday. Portland: Tin House Books. 